\title{
Osteoradionecrosis in a Patient Submitted to Head and Neck Radiotherapy: A Case Report
}

\author{
Osteoradionecrosis en un Paciente Sometido a \\ Radioterapia de Cabeza y Cuello: Reporte de un Caso
}

\begin{abstract}
Karla Daniella Malta Ferreira1; Patrícia Dias Corrêa; Giovanna Rodrigues Balenzio; Fernanda Mombrini Pigatti ${ }^{3}$; Dennis de Carvalho Ferreira ${ }^{4}$ \& Patricia Nivoloni Tannure ${ }^{4}$
\end{abstract}

FERREIRA, K. D. M.; CORRÊA, P. D.; BALENZIO, G. R.; PIGATTI, F. M.; FERREIRA, D. C. \& TANNURE, P. N. Osteoradionecrosis in a patient submitted to head and neck radiotherapy: A case report. Int. J. Odontostomato., 13(4):428432, 2019.

ABSTRACT: Radiotherapy applies ionizing radiation at predetermined doses for a limited period of time in order to destroy tumors. The oral cavity, which has a high rate of cell renewal, is affected by the side effects of radiotherapy including osteoradionecrosis (ORN). This condition occurs due to irradiated bone tissue that becomes devitalized and exposed in the oral cavity. Conservative therapies are recommended for ORN lesions that are not extensive or in an early stage. Surgical intervention is necessary for extensive areas affected by necrosis. This study reports a case of ORN in the left mandibular body which resulted in a pathological fracture. The treatment consisted of segmental mandibulectomy and the use of a reconstruction plate. Also, low-level laser therapy around bone exposure was performed. After surgery, the patient underwent 6 months of follow-up and was satisfied with the outcome. However, the patient died before control of ORN was achieved due to a heart attack.

KEY WORDS: osteoradionecrosis, radiotherapy, head and neck neoplasms, mandibular osteotomy.

\section{INTRODUCTION}

In Brazil, it is estimated there will be 600.000 new cases of cancer in 2018 and of these 33.160 will involve the region of the head and neck (Ministério da Saúde, 2018). The treatment of these cancers depends on factors such as the location of the tumor, degree of malignancy, clinical staging, and general health of the patient. Surgery with a safety margin for tumor removal and radiotherapy (RT) with or without chemotherapy are the treatment alternatives most often indicated (Sathasivam et al., 2018).

RT uses ionizing radiation at predetermined doses over a period of time, to cause cell death or loss of replicative capacity of the neoplastic cells. As it is a non-selective treatment, malignant cells and healthy cells are affected (Baskar et al., 2014). Radiation decreases blood flow, reduces nutrients and the number of defense cells. The "3 H's" theory, proposed by Marx (1983), is based on hypoxia, hypovascularity and hypocellularity induced by radiation. These three factors contribute to a failure of metabolic capacities and a decrease in the repair and healing capacities of irradiated bone tissue (Chronopoulos et al., 2018).

The diagnosis of osteoradionecrosis (ORN) is both complex and challenging, based on clinical findings, such as an absence of cancer recurrence, devitalized bone tissue due to radiation, and bone exposure without healing over a 3 to 6 -month period (Sathasivam et al.; Chronopoulos et al.).

High doses of radiation along with other factors such as poor oral hygiene, periodontal disease, extensive caries, dentoalveolar abscesses, anatomical

\footnotetext{
${ }^{1}$ Servicio de Cirugía Oral y Maxilofacial, Hospital Evangélico de Cachoeiro de Itapemirim, Espírito Santo, Brazil.

${ }^{2}$ Cirujana Dentista, Práctica privada, Espírito Santo, Brazil.

${ }^{3}$ Universidad Federal de Juiz de Fora campus Governador Valadares, Minas Gerais, Brazil.

${ }^{4}$ Universidad Veiga de Almeida. Universidad Estacio de Sá, Rio de Janeiro, Brazil.
} 
location of the tumor, dental surgeries during or after radiotherapy, trauma due to poorly adapted prosthesis, systemic diseases, alcoholism and smoking are all risk factors for ORN (Marx; Sathasivam et al.).

ORN can affect the patient's quality of life since it can cause severe pain, extra and intraoral fistulae, pathological fractures, systemic infections, trismus, masticatory and phonetic difficulties, fetid odor, as well as dysgeusia and dysesthesia (Sathasivam et al.; Monteiro et al., 2005; Franco et al., 2017; Chronopoulos et al.).

ORN treatment includes conservative and surgical measures. The more conservative initial treatment includes wound cleaning and debriding combined with drug therapy to relieve the symptomatology of the disease. In more severe cases, sequestrectomy or a more radical surgical treatment is performed; that is segmental mandibulectomy with mandibular reconstruction (Rommel et al., 2017). Also, nowadays low-level laser is used to treat various lesions due to its analgesic and anti-inflammatory actions, with favorable results in the recuperation of bone tissues (Ribeiro et al., 2018).

Despite these alternatives, the treatment of ORN is still a clinical challenge and is dependent on a multidisciplinary team. Considering the relevance of the subject, we report here the case of a patient with osteoradionecrosis in the left mandibular body submitted to a partial mandibulectomy with mandibular reconstruction to control the lesion.

\section{CASE REPORT}

A 41-year-old male presented at the hospital in April 2016 with intense pain, trismus, and persistent infection in the left jaw region. These symptoms developed after third molar extraction in December 2015.

His medical history recorded oral cavity neoplasia (squamous cell carcinoma) in floor of mouth, which was diagnosed in 2014, and was treated with three cycles of chemotherapy and 39 sessions of radiotherapy with $180 \mathrm{cGy}$ doses each; the last session was on 09/30/2014. The patient was a chronic alcoholic and active smoker, with depression, and took Diazepam $10 \mathrm{mg}$ and Carbamazepine $200 \mathrm{mg}$.
The extra-oral examination showed facial asymmetry due to edema in the left mandibular angle region. Also, were observed the presence of a fistula, an erythematous area and limited oral opening (approximately $15 \mathrm{~mm}$ ). The intraoral oral examination revealed an area of exposed bone in the region of the left mandibular body, malodorous, and a spontaneous purulent secretion.

The orthopantomography showed areas of diffuse radiolucency and processes of bone destruction compatible with the pathological fracture of the left mandibular body and suggestive of osteoradionecrosis, also evidenced by computed tomography (Fig. 1).

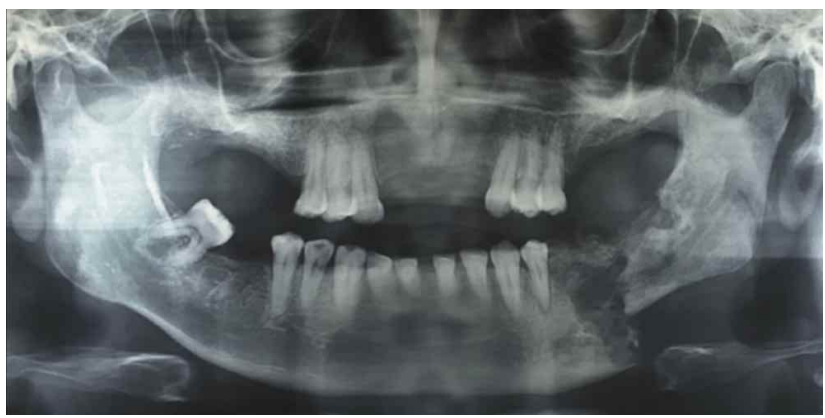

Fig. 1. Orthopantomography demonstrating the initial aspect of the bone lesion and the fracture of the jaw body on the left side.

The diagnostic hypothesis was osteoradionecrosis. The initial treatment consisted of antibiotic therapy (Cephalexin $500 \mathrm{mg}, 06 / 06 \mathrm{~h}$, for 7 days and Metronidazole $400 \mathrm{mg}, 08 / 08 \mathrm{~h}$, for 7 days), mouthwashes with chlorhexidine $0.12 \%$ (3 times a day, for 14 days), oral hygiene instructions and interruption of alcohol and tobacco consumption.

After the purulent flow had ceased spontaneouslysurgical treatment (partial mandibulectomy with mandibular reconstruction) under general anesthesia (nasotracheal intubation) was undertaken. This treatment began with an incision below the mandibular basal followed by removal of the necrotic stump using a dental reciprocating saw and irrigation with $0.9 \%$ saline solution until bone marrow bleeding was observed at the extremities. The mandible was partially reconstructed with a 12-hole $2.4 \mathrm{~mm}$ reconstruction plate (Fig. 2). The necrotic bone removed was sent for anatomopathological examination which confirmed the diagnosis of osteonecrosis. The patient was hospitalized for 7 days for pain control and venous antibiotic therapy (Cephalothin, $1 \mathrm{~g} \mathrm{06/06} \mathrm{h).} \mathrm{After}$ discharge from the hospital the patient was instructed 
to perform rigorous oral hygiene, and mouthwashes with chlorhexidine $0.12 \%$ and in the case of pain to take an analgesic (dipyrone sodium $500 \mathrm{mg}$ ).

Laser phototherapeutic sessions were carried out in the immediate post-surgical period and weekly for bone and tissue stimulation. For the low-level laser therapy, a diode laser (Therapy EC, DMC, São Carlos, SP, Brazil) with a wavelength of $660 \mathrm{~nm}$ was used. The power used was $100 \mathrm{~mW}$, energy density of $35 \mathrm{~J} /$ $\mathrm{cm} 2$ and energy per point of $1 \mathrm{~J}$. Irradiation time was 10 seconds per point based on the laser beam spot size of $0.028 \mathrm{~cm}^{2}$ around the bone exposure. The patient continued followed-up with periodic visits to the outpatient service (every 3 months); and he was satisfied with the treatment received (Figs. 3 and 4). However, the patient died before ORN control was achieved, due to a heart attack.

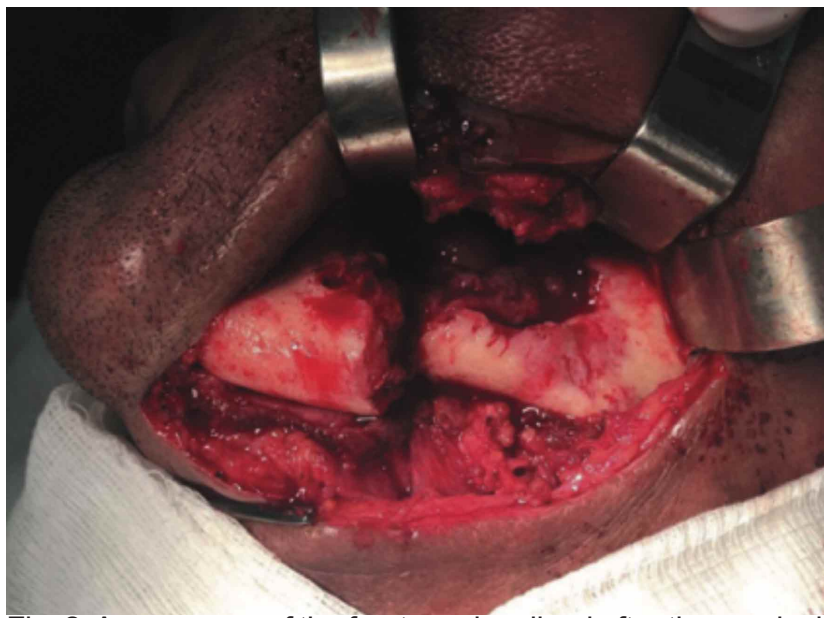

Fig. 2. Appearance of the fracture visualized after the surgical incision.

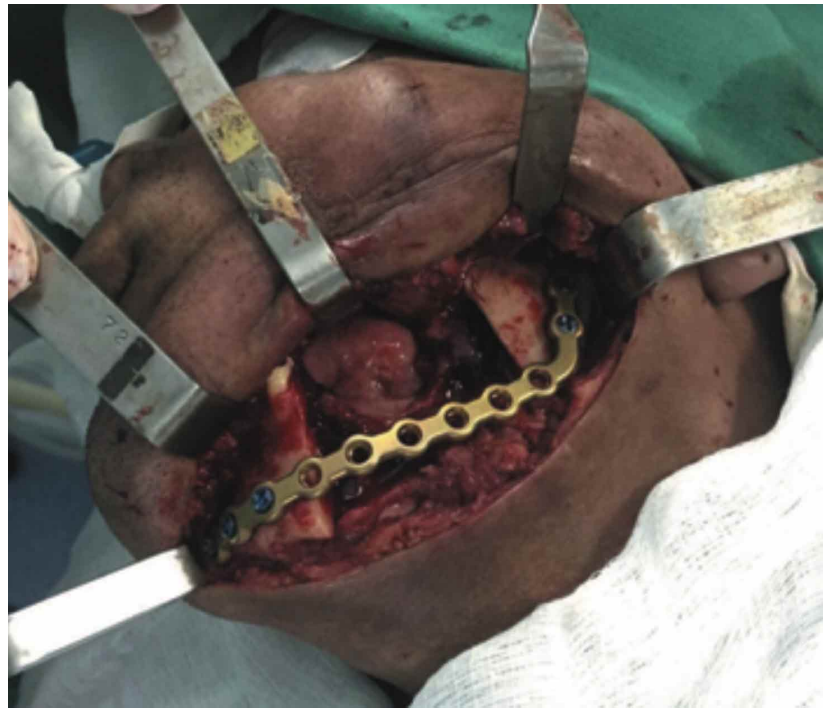

Fig. 3. Reconstruction plate installed during the trans-surgical period.

\section{DISCUSSION}

ORN is a severe and complex sequel of head and neck RT that may cause deep biological, sociological and psychological impacts on the quality of life of patients. Dental hygiene and tooth extractions have historically been considered one of the most important risk factors and mandibular ORN developed in $5.5 \%$ of head and neck cancer patients (Moon et al., 2017).

Sathasivam et al. proposed that the diagnosis of ORN be made after 1 month of bone exposure without healing, recommended that smokers should
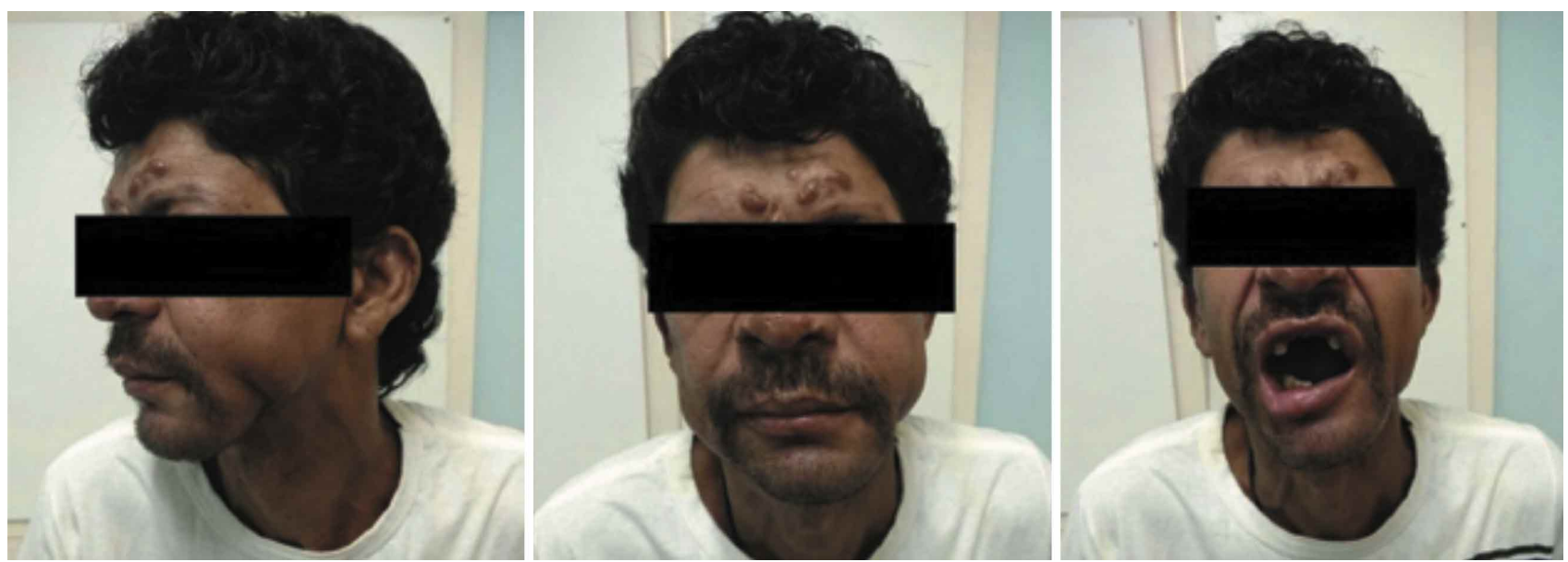

Fig. 4. Clinical aspect of the patient 3 months after surgery. 
be strongly advised to quit; patients with Type II Diabetes Mellitus should be instructed to maintain controlled blood glucose levels; a trained dental surgeon should be consulted at least 1 month prior to $\mathrm{RT}$ and to any extractions to be performed before the start of radiotherapy treatment; also patients who require oral surgery after RT should be monitored for 2 weeks to evaluate bone healing; and finally patients who had already had head and neck RT should be regularly followed up by trained dentists.

According to Marx the effects caused by radiation in the tissues seem to be progressive over the years, and of increasingly severe intensity. Numerous studies have reported a relationship between maximum RT doses >60-75 Gy with the development of ORN (Chen et al., 2016; Owosho et al., 2017). However, specific dosimetric parameters to help guide RT planning is limited. However, a recent study by Moon et al. did not demonstrate any significant differences in dosimetry between patients with and without ORN. The currently accepted dose constraint is Dmax<70 Gy.

In another recent retrospective study 325 patients irradiated for head and neck cancer were assessed for ORN risk factors. Among the total sample, 59 patients developed ORN, all of whom had received doses above 65Gy. Fifty-six cases (94.9\%) occurred in the mandible and $13.6 \%$ in the place where dental extractions had been performed. A total of $88.1 \%$ of the cases occurred in patients less than 12 months after the last RT session. Smoking was associated with the occurrence of ORN (Sathasivam et al.).

Chrcanovic et al. (2010) shows that ORN occurs three times more in the mandible than in the maxilla. This is due to the lower blood supply in the mandibular, the more compact bone structure and the location where there is a greater chance of contact withradiation when it is applied to the more common tumor sites of the oral cavity, such as the tongue, retromolar region and buccal floor.

Several therapeutic options are postulated for the treatment of ORN, depending on the severity of the condition. Conservative management, including antibiotics, improved oral hygiene, analgesics, and hyperbaric oxygen, is recommended for early and lowgrade ORN forms. However, in cases of high-dose radiation or more advanced ORN, including orocutaneous fistula, extensive bone and soft tissue defects, and pathological fractures, conservative treatment is not sufficient and surgical treatment is required (Rommel et al.).

Studies have shown that bone tissue irradiated with low-level laser aiming to promote osteogenesis may increase vascularization, accelerate the biological processes involved in the repair of lesions, increase the calcification of the bone matrix and provide greater mechanical resistance of the newformed bone tissue (Franco et al.; Ribeiro et al.).

The analysis of several studies leads us to highlight the risk of developing ORN in patients submitted to head and neck radiotherapy if they undergo surgical procedures in the irradiated area. Thus, there is a need for a combination of therapies aimed at success in the healing process.

\section{CONCLUSION}

According to the progression of the reported case, we conclude that ORN brings effects that cause great discomfort and affect patients' quality of life. Therefore, it is up to the dentist to pay attention to the prevention of osteoradionecrosis through prophylactic and curative measures. Finally, it is essential the effective presence of a dentist in multidisciplinary oncological teams conducting evaluations before, during and after radiotherapy treatments. Based on this, we emphasize that the prevention of bone necrosis is still the best way to perform ORN treatment based on the patient's awareness and collaboration about the disease and the strict maintenance of his oral health.

FERREIRA, K. D. M.; CORRÊA, P. D.; BALENZIO, G. R.; PIGATTI, F. M.; FERREIRA, D. C. \& TANNURE, P. N. Osteoradionecrosis en un paciente sometido a radioterapia de cabeza y cuello: Reporte de un caso. Int. J. Odontostomat., 13(4):428-432, 2019.

RESUMEN: La radioterapia aplica radiación ionizante a dosis predeterminadas durante un período de tiempo limitado para destruir tumores. La cavidad oral, que tiene una alta tasa de renovación celular, se ve afectada por los efectos secundarios de la radioterapia, incluida la osteorradionecrosis (ORN). Esta condición se produce debido al tejido óseo irradiado que se desvitaliza y expone en la cavidad oral. Se recomiendan terapias conservadoras para las lesiones de ORN que no son extensas o en una etapa temprana. La intervención quirúrgica es necesaria para áreas extensas afectadas por necrosis. Este estudio reporta un caso de ORN en el cuerpo mandibular izquierdo que resultó 
en una fractura patológica. El tratamiento consistió en mandibulectomía segmentaria y el uso de una placa de reconstrucción. Además, se realizó una terapia con láser de bajo nivel alrededor de la exposición ósea. Después de la cirugía, el paciente se sometió a 6 meses de seguimiento y quedó satisfecho con el resultado. Sin embargo, el paciente falleció antes de que se lograra el control de ORN debido a un ataque cardíaco.

PALABRAS CLAVE: osteorradionecrosis, radioterapia, neoplasias de cabeza y cuello, osteotomía mandibular.

\section{REFERENCES}

Baskar, R.; Dai, J.; Wenlong, N.; Yeo, R. \& Yeoh, K. W. Biological response of cancer cells to radiation treatment. Front. Mol. Biosci., $1: 24,2014$

Chen, J. A.; Wang, C. C.; Wong, Y. K.; Wang, C. P.; Jiang, R. S.; Lin, J. C.; Chen, C. C. \& Liu, S. A. Osteoradionecrosis of mandible bone in patients with oral cancer--associated factors and treatment outcomes. Head Neck, 38(5):762-8, 2016.

Chrcanovic, B. R.; Reher, P.; Sousa, A. A. \& Harris, M. Osteoradionecrosis of the jaws--a current overview--part 1 : Physiopathology and risk and predisposing factors. Oral Maxillofac. Surg., 14(1):3-16, 2010.

Chronopoulos, A.; Zarra, T.; Ehrenfeld, M. \& Otto, S. Osteoradionecrosis of the jaws: definition, epidemiology, staging and clinical and radiological findings. A concise review. A concise review. Int. Dent. J., 68(1):22-30, 2018.

Franco, T.; Cezini, M. D. C.; Metropolo, L.; Ferreira, D. C. \& Tannure, P. N. Success of preventive approach to mandibular osteoradionecrosis in an adolescent: case report. Oral Surg., 10(4):e104-9, 2017

Marx, R. E. Osteoradionecrosis: a new concept of its pathophysiology. J. Oral Maxillofac. Surg., 41(5):283-8, 1983.

Ministério da Saúde. Estimativa 2018: Incidência de câncer no Brasil. Rio de Janeiro, INCA, 2018.

Moon, D. H.; Moon, S. H.; Wang, K.; Weissler, M. C.; Hackman, T. G.; Zanation, A. M.; Thorp, B. D.; Patel, S. N.; Zevallos, J. P.; Marks, L. B.; et al. Incidence of, and risk factors for, mandibular osteoradionecrosis in patients with oral cavity and oropharynx cancers. Oral Oncol., 72:98-103, 2017.

Owosho, A. A.; Tsai, C. J.; Lee, R. S.; Freymiller, H.; Kadempour, A.; Varthis, S.; Sax, A. Z.; Rosen, E. B.; Yom, S. K.; Randazzo, J.; et al. The prevalence and risk factors associated with osteoradionecrosis of the jaw in oral and oropharyngeal cancer patients treated with intensity-modulated radiation therapy (IMRT): The Memorial Sloan Kettering Cancer Center experience. Oral Oncol., 64:44-51, 2017.

Ribeiro, G. H.; Minamisako, M. C.; Rath, I. B. S.; Santos, A. M. B.; Simões, A.; Pereira, K. C. R. \& Grando, L. J. Osteoradionecrosis of the jaws: case series treated with adjuvant low-level laser therapy and antimicrobial photodynamic therapy. J. Appl. Oral Sci., 26:e20170172, 2018.

Sathasivam, H. P.; Davies, G. R. \& Boyd, N. M. Predictive factors for osteoradionecrosis of the jaws: A retrospective study. Head Neck, 40(1):46-54, 2018.
Corresponding author:

Fernanda Mombrini PIGATTI

Universidad Federal de Juiz de Fora campus Governador Valadares

Minas Gerais

BRAZIL

Email: fer.pigatti@gmail.com

Received: 23-05-2019

Accepted: 28-06-2019 